\title{
Global coral disease prevalence associated with sea temperature anomalies and local factors
}

\author{
Diego Ruiz-Moreno ${ }^{1, *}$, Bette L. Willis ${ }^{2}$, A. Cathie Page $^{2}$, Ernesto Weil ${ }^{3}$, \\ Aldo Cróquer ${ }^{4}$, Bernardo Vargas-Angel ${ }^{5}$, Adán Guillermo Jordan-Garza ${ }^{6}$, \\ Eric Jordán-Dahlgren ${ }^{6}$, Laurie Raymundo ${ }^{7}$, C. Drew Harvell ${ }^{1}$ \\ ${ }^{1}$ Department of Ecology and Evolutionary Biology, Cornell University, Ithaca, New York 14853, USA \\ ${ }^{2}$ ARC Centre of Excellence for Coral Reef Studies, and School of Marine and Tropical Biology, James Cook University, \\ Townsville, Queensland 4811, Australia \\ ${ }^{3}$ Department of Marine Sciences, University of Puerto Rico, PO Box 9000, Mayaguez 00681, Puerto Rico \\ ${ }^{4}$ Departamento de Estudios Ambientales, Universidad Simón Bolívar, Apartado 89000, Caracas 1080-A, Venezuela \\ ${ }^{5}$ Joint Institute for Marine and Atmospheric Research, University of Hawaii, 1000 Pope Road, Honolulu, Hawaii 96822, USA \\ ${ }^{6}$ Instituto de Ciencias del Mar y Limnología, Universidad Nacional Autónoma de México, Apartado Postal 1152, \\ 77500 Cancún, Quintana Roo, México \\ ${ }^{7}$ University of Guam Marine Laboratory, UOG Station, Mangilao, Guam 96923, USA
}

\begin{abstract}
Coral diseases are taking an increasing toll on coral reef structure and biodiversity and are important indicators of declining health in the oceans. We implemented standardized coral disease surveys to pinpoint hotspots of coral disease, reveal vulnerable coral families and test hypotheses about climate drivers from 39 locations worldwide. We analyzed a 3 yr study of coral disease prevalence to identify links between disease and a range of covariates, including thermal anomalies (from satellite data), location and coral cover, using a Generalized Linear Mixed Model. Prevalence of unhealthy corals, i.e. those with signs of known diseases or with other signs of compromised health, exceeded $10 \%$ on many reefs and ranged to over $50 \%$ on some. Disease prevalence exceeded $10 \%$ on $20 \%$ of Caribbean reefs and $2.7 \%$ of Pacific reefs surveyed. Within the same coral families across oceans, prevalence of unhealthy colonies was higher and some diseases were more common at sites in the Caribbean than those in the Pacific. The effects of high disease prevalence are potentially extensive given that the most affected coral families, the acroporids, faviids and siderastreids, are among the major reef-builders at these sites. The poritids and agaricids stood out in the Caribbean as being the most resistant to disease, even though these families were abundant in our surveys. Regional warm temperature anomalies were strongly correlated with high disease prevalence. The levels of disease reported here will provide a much-needed local reference point against which to compare future change.
\end{abstract}

KEY WORDS: Coral health - Reef-building coral families - Caribbean Sea - Pacific Ocean · Generalized Linear Mixed Model · Infectious diseases · Coral disease prevalence

Resale or republication not permitted without written consent of the publisher

\section{INTRODUCTION}

Outbreaks of coral diseases are a major contributor to coral mortality and also reduce coral growth and recruitment (Sutherland \& Ritchie 2004, Miller et al. 2006, Weil et al. 2006, Bruno et al. 2007, Harvell et al.
2007, 2009, Weil \& Cróquer 2009). In the Caribbean, repeated outbreaks starting in the 1980s contributed to mass mortalities that severely reduced populations of the once-dominant corals Acropora palmata and A. cervicornis (Hughes 1994, Richardson 1998, Aronson \& Precth 2001, Sutherland \& Ritchie 2004, Miller 
et al. 2006, Weil et al. 2006, Harvell et al. 2007, Rogers 2009, Weil \& Cróquer 2009). In the IndoPacific, significant coral diseases have been reported in the Philippines (PH) (Raymundo et al. 2005), Guam (Myers \& Raymundo 2009), and the Great Barrier Reef (GBR) (Willis et al. 2004, Sato et al. 2009) and might underlie or at least contribute to the increasing rate of coral cover decline in this region (Bruno \& Selig 2007). Coral diseases also appear to be emerging in East Africa (McClanahan 2004) and Hawaii (Aeby 2006, Abey et al. 2011).

Climate variability may impact highly sensitive coral reefs through at least 3 different mechanisms (Mydlarz et al. 2009): (1) extreme warm temperatures in summer can disrupt the obligate symbiosis between the coral and its endosymbiotic algal partner (Hoegh-Guldberg et al. 2007); (2) winter warming may enable the persistence of pathogens at higher abundances than in past decades (Ford 1996, Harvell et al. 2009); and (3) ocean acidification reduces the ability of corals to build skeletons (Hoegh-Guldberg et al. 2007, Carpenter et al. 2008), potentially reducing coral resistance to pathogens and possibly affecting pathogen virulence. In addition, anthropogenic activities that increase nutrient loads in reef waters may diminish the health of corals (Bruno et al. 2003, Weil 2004, Jordán-Dahlgren et al. 2005, Voss \& Richardson 2006, Baker et al. 2007, Bruno \& Selig 2007, Harvell et al. 2007, Sandin et al. 2008, Garren et al. 2009). Strong associations found between the abundance of growth anomalies on the coral genera Acropora and Porites and both host density and human population size across the IndoPacific provide further support for links between anthropogenic activities and coral health (Aeby et al. 2011). Levels of coral disease are an important indicator of coral reef health and have been correlated with climate warming events (McClanahan 2004, Bruno et al. 2007, Maynard et al. 2008, 2011, Muller \& van Woesik 2009, Heron et al. 2010). However, assessment of climate change-related impacts is particularly challenging for coral reef ecosystems because of shifting baselines (i.e. redefinition of what constitutes a healthy reef state) (Pauly 1995), and the combined effects of factors other than climate on reefs. The prevalence values for multiple diseases at a number of locations globally reported here provide a reference point against which to measure future changes.

Here, we report levels of disease prevalence determined in a quantitative 3 yr survey program encompassing 39 reef sites in the Caribbean and Pacific. This data set allows us to identify the regions and coral families with high disease prevalence and test the role of temperature anomalies and more local factors, such as coral cover, diversity, geographic location, area surveyed, and an rough indicator of reef health, in facilitating disease outbreaks.

\section{MATERIALS AND METHODS}

\section{Data collection}

Ten reef regions were defined based on geographic proximity of the 39 reef sites surveyed (Fig. 1, Table 1). These 10 regions aggregate information from a number of reefs or localities, and each reef aggregates information from sites and transects within sites, for a total of 253, 382 and 452 transects for the years 2005, 2006 and 2007 respectively (Table 1). Due to weather conditions, not all sites were sampled all years (Tables S1 \& S2 in the supplement at www.int-res.com/articles/suppl/d100p249_ supp.pdf show sites and years).

Comprehensive data were collected using a standardized survey protocol. An underwater measuring tape was laid parallel to depth contours as the transect centerline, and divers surveyed a $1 \mathrm{~m}$ wide path along each side of the tape. Within the belt-transect, each scleractinian colony was identified to family, and its health status was determined (i.e. whether or not each colony showed signs of any of the diseases or compromised health categories defined in Beeden et al. (2008) for Indo-Pacific corals or in Weil \& Hooten (2008) for Caribbean corals. The central tape was also utilized to estimate percent cover of each coral genus or family, as well as the other main benthic groups (including fleshy macroalgae, soft corals, rocks, sand, rubble, silt), using the line intercept technique (Montebon 1992).

All unhealthy signs were recorded as 1 of 12 disease categories or 6 compromised health conditions (CHC) (i.e. conditions apparently not infectious but likely to compromise host defenses or representing potential entry wounds) that include some uncharacterized lesions (Table 2). Unhealthy signs were identified using decision trees developed previously (Beeden et al. 2008, Raymundo et al. 2008, Weil \& Hooten 2008).

We defined 6 sea surface temperature (SST) indices using the weekly SST value for each location (the mean of the pixels corresponding to the Von Neumann neighbors of a locality was used when data were missing) for the period from 1985 to 2007 (maximum temporal interval available for all locations) 
NWHI

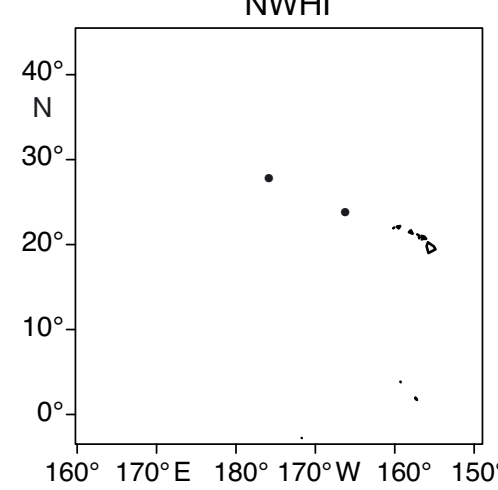

Caribbean

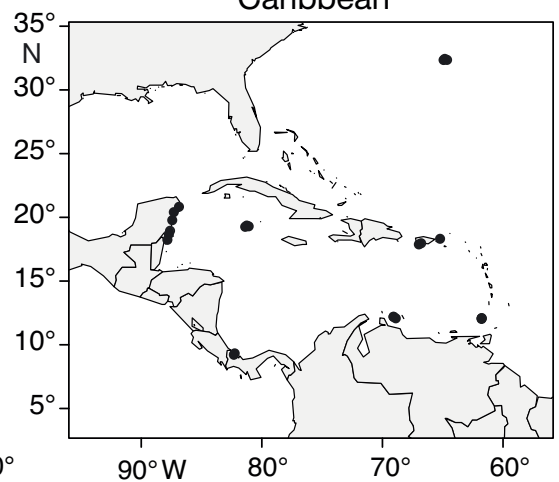

$\mathrm{PH}$ and $\mathrm{GBR}$

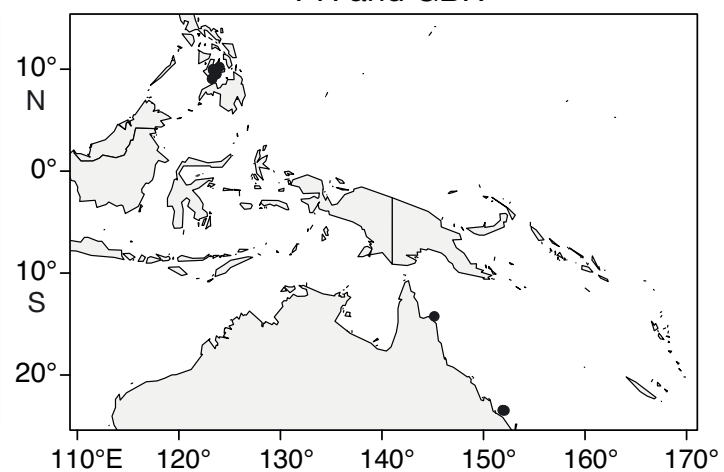

Fig. 1. Regions showing locations of the sites $(\bullet)$ where corals were surveyed. See Table 1 for a list of the locations and geographic coordinates. NWHI: Northwestern Hawaiian Islands; PH: Philippines; GBR: Great Barrier Reef

Table 1. Sampling sites identified to region, locality in region and number of transects per locality. The column 'Minimum no. of transects' refers to the minimum number of transects across all sampling years (no. of locations $\times$ no. of transects) (see Tables S1 and S2 in the supplement at www.int-res.com/articles/suppl/d100p249_supp.pdf for a year by year description of the sampling locations). STRI: Smithsonian Tropical Research Institute, MPA: Marine Protected Area

\begin{tabular}{|c|c|c|c|c|c|}
\hline Region & Site & Latitude & Longitude & $\begin{array}{l}\text { Minimum no. of } \\
\text { transects }\end{array}$ & $\begin{array}{c}\text { Transect size } \\
\text { (m) }\end{array}$ \\
\hline \multicolumn{6}{|l|}{ Caribbean } \\
\hline Bermuda & Chub Cut & $32.35^{\circ} \mathrm{N}$ & $64.93^{\circ} \mathrm{W}$ & $2 \times 5$ & $10 \times 2$ \\
\hline Bermuda & Rita's & $32.36^{\circ} \mathrm{N}$ & $64.64^{\circ} \mathrm{W}$ & $2 \times 5$ & $10 \times 2$ \\
\hline Bermuda & Snake Pit & $32.44^{\circ} \mathrm{N}$ & $64.83^{\circ} \mathrm{W}$ & $2 \times 5$ & $10 \times 2$ \\
\hline Cayman Islands & Andes Wall & $19.36^{\circ} \mathrm{N}$ & $81.25^{\circ} \mathrm{W}$ & $2 \times 5$ & $10 \times 2$ \\
\hline Cayman Islands & East site & $19.3^{\circ} \mathrm{N}$ & $81.09^{\circ} \mathrm{W}$ & $2 \times 5$ & $10 \times 2$ \\
\hline Cayman Islands & South Point & $19.26^{\circ} \mathrm{N}$ & $81.38^{\circ} \mathrm{W}$ & $2 \times 5$ & $10 \times 2$ \\
\hline Curacao & CCS Bay & $12.2^{\circ} \mathrm{N}$ & $69.08^{\circ} \mathrm{W}$ & $2 \times 5$ & $10 \times 2$ \\
\hline Curacao & Habitat Hotel & $12.2^{\circ} \mathrm{N}$ & $69.08^{\circ} \mathrm{W}$ & $2 \times 5$ & $10 \times 2$ \\
\hline Curacao & SeaAquarium & $12.08^{\circ} \mathrm{N}$ & $68.89^{\circ} \mathrm{W}$ & $2 \times 5$ & $10 \times 2$ \\
\hline Grenada & Dragon & $12.09^{\circ} \mathrm{N}$ & $61.78^{\circ} \mathrm{W}$ & $2 \times 5$ & $10 \times 2$ \\
\hline Grenada & Flamingo Bay & $12.09^{\circ} \mathrm{N}$ & $61.76^{\circ} \mathrm{W}$ & $2 \times 5$ & $10 \times 2$ \\
\hline Grenada & Valleys & $12.03^{\circ} \mathrm{N}$ & $61.78^{\circ} \mathrm{W}$ & $2 \times 5$ & $10 \times 2$ \\
\hline Mexican Yucatan & Akumal & $20.41^{\circ} \mathrm{N}$ & $87.3^{\circ} \mathrm{W}$ & $2 \times 6$ & $25 \times 2$ \\
\hline Mexican Yucatan & Mahahual & $18.69^{\circ} \mathrm{N}$ & $87.71^{\circ} \mathrm{W}$ & $3 \times 6$ & $25 \times 2$ \\
\hline Mexican Yucatan & Puerto Morelos & $20.83^{\circ} \mathrm{N}$ & $86.87^{\circ} \mathrm{W}$ & $2 \times 6$ & $25 \times 2$ \\
\hline Mexican Yucatan & Punta Allen & $19.78^{\circ} \mathrm{N}$ & $87.43^{\circ} \mathrm{W}$ & $4 \times 6$ & $25 \times 2$ \\
\hline Mexican Yucatan & Uvero & $18.95^{\circ} \mathrm{N}$ & $87.61^{\circ} \mathrm{W}$ & $2 \times 6$ & $25 \times 2$ \\
\hline Mexican Yucatan & Xcalak & $18.24^{\circ} \mathrm{N}$ & $87.83^{\circ} \mathrm{W}$ & $3 \times 6$ & $25 \times 2$ \\
\hline Panama & Cayo Roldan & $9.22^{\circ} \mathrm{N}$ & $82.32^{\circ} \mathrm{W}$ & $2 \times 5$ & $10 \times 2$ \\
\hline Panama & Isla Colon (STRI) & $9.33^{\circ} \mathrm{N}$ & $82.25^{\circ} \mathrm{W}$ & $2 \times 5$ & $10 \times 2$ \\
\hline Puerto Rico & Boya & $17.88^{\circ} \mathrm{N}$ & $66.98^{\circ} \mathrm{W}$ & $2 \times 5$ & $10 \times 2$ \\
\hline Puerto Rico & Culebrita & $18.32^{\circ} \mathrm{N}$ & $65.22^{\circ} \mathrm{W}$ & $2 \times 5$ & $10 \times 2$ \\
\hline Puerto Rico & Guanica & $17.97^{\circ} \mathrm{N}$ & $66.79^{\circ} \mathrm{W}$ & $2 \times 5$ & $10 \times 2$ \\
\hline \multicolumn{6}{|l|}{ Pacific } \\
\hline GBR & Heron Island & $23.44^{\circ} \mathrm{S}$ & $151.93^{\circ} \mathrm{E}$ & $4 \times 3$ & $20 \times 2$ \\
\hline GBR & One Tree Island & $23.48^{\circ} \mathrm{S}$ & $152.07^{\circ} \mathrm{E}$ & $2 \times 3$ & $20 \times 2$ \\
\hline GBR & Wistari Reef & $23.45^{\circ} \mathrm{S}$ & $151.89^{\circ} \mathrm{E}$ & $2 \times 3$ & $20 \times 2$ \\
\hline GBR & Lizard Island & $14.24^{\circ} \mathrm{S}$ & $145.16^{\circ} \mathrm{E}$ & $2 \times 3$ & $20 \times 2$ \\
\hline NWHI & French Frigate & $23.8^{\circ} \mathrm{N}$ & $166.24^{\circ} \mathrm{W}$ & $1 \times 39$ & $2.5 \times 1$ \\
\hline NWHI & Pearl \& Hermes & $27.86^{\circ} \mathrm{N}$ & $175.85^{\circ} \mathrm{W}$ & $1 \times 37$ & $2.5 \times 1$ \\
\hline $\mathrm{PH}$ & Apo Fished & $9.07^{\circ} \mathrm{N}$ & $123.27^{\circ} \mathrm{E}$ & $1 \times 3$ & $20 \times 1$ \\
\hline $\mathrm{PH}$ & Apo MPA & $9.07^{\circ} \mathrm{N}$ & $123.27^{\circ} \mathrm{E}$ & $1 \times 3$ & $20 \times 1$ \\
\hline $\mathrm{PH}$ & Balicasag Fished & $9.94^{\circ} \mathrm{N}$ & $123.37^{\circ} \mathrm{E}$ & $1 \times 3$ & $20 \times 1$ \\
\hline $\mathrm{PH}$ & Balicasag MPA & $9.94^{\circ} \mathrm{N}$ & $123.37^{\circ} \mathrm{E}$ & $1 \times 3$ & $20 \times 1$ \\
\hline $\mathrm{PH}$ & Basdiot Fished & $10^{\circ} \mathrm{N}$ & $123.38^{\circ} \mathrm{E}$ & $1 \times 3$ & $20 \times 1$ \\
\hline $\mathrm{PH}$ & Basdiot MPA & $10^{\circ} \mathrm{N}$ & $123.38^{\circ} \mathrm{E}$ & $1 \times 3$ & $20 \times 1$ \\
\hline $\mathrm{PH}$ & Gilutungan Fished & $10.21^{\circ} \mathrm{N}$ & $123.98^{\circ} \mathrm{E}$ & $1 \times 3$ & $20 \times 1$ \\
\hline $\mathrm{PH}$ & Gilutungan MPA & $10.21^{\circ} \mathrm{N}$ & $123.98^{\circ} \mathrm{E}$ & $1 \times 3$ & $20 \times 1$ \\
\hline $\mathrm{PH}$ & Saavedra Fished & $9.52^{\circ} \mathrm{N}$ & $123.68^{\circ} \mathrm{E}$ & $1 \times 3$ & $20 \times 1$ \\
\hline $\mathrm{PH}$ & Saavedra MPA & $9.52^{\circ} \mathrm{N}$ & $123.68^{\circ} \mathrm{E}$ & $1 \times 3$ & $20 \times 1$ \\
\hline
\end{tabular}


Table 2. Disease categories and compromised health conditions found on Caribbean and Pacific corals. Each scleractinian colony was checked for the symptoms of these diseases and health conditions

\begin{tabular}{ll}
$\begin{array}{l}\text { Disease } \\
\text { category }\end{array}$ & Diseases included in this category \\
\hline AtN & Atramentous necrosis \\
BBD & Black band disease \\
BLS & Non-thermal bleached spots \\
BRB & Brown band disease \\
CCI & Caribbean ciliate infections \\
DS & Dark spots \\
GA & Growth anomalies \\
CHC & Group of compromised health conditions: \\
& Dark blotch disease, abnormal mucus and \\
& sediments, necrosis, pigmentation \\
& response, thermal bleaching, and other \\
SEB & unclassified signs \\
TDL & Skeleton eroding band \\
UWS & Thin dark line \\
WSS & Ulcerative white signs \\
YB & Yellow bands \\
&
\end{tabular}

from the $4 \mathrm{~km}$ Pathfinder (version 4.1) dataset at the National Oceanographic Data Center (NODC) and the University of Miami's Rosenstiel School of Marine and Atmospheric Science (RSMAS), which is an extension of, and improvement on, the SST fields from the older NOAA/NASA Advanced Very High Resolution Radiometer (AVHRR) Oceans Pathfinder project (Kilpatrick et al. 2001). For each locality, the SST values corresponding to the 12 mo immediately preceding the date of sampling were used to calculate the 6 thermal anomaly indices (using the weekly average over $23 \mathrm{yr}$ as a reference value). The weekly SST anomaly indices are:

- SST1: frequency of weeks that have temperatures over the mean SST plus $1^{\circ} \mathrm{C}$

- SST2: frequency of weeks that have temperatures under the mean SST minus $1{ }^{\circ} \mathrm{C}$

- SST3: summation of the temperatures corresponding to SST1

- SST4: summation of the temperatures corresponding to SST2

- SST5: maximum anomaly value registered (over the mean SST plus $1^{\circ} \mathrm{C}$ )

- SST6: minimum anomaly value registered (under the mean SST minus $1^{\circ} \mathrm{C}$ )

Hence, SST1 (SST2) measures the frequency of warm (cold) temperature events in the year prior to data collection, SST3 and SST4 accumulate the intensity of such thermal stress, and SST5 and SST6 registered the extreme values. The rationale behind these indices is that SST1, SST3 and SST5 might exert a favorable influence on pathogens and facilitate disease, and SST2, SST4 and SST6 might have negative effects on pathogens and inhibit disease. In general, we expect all thermal anomaly metrics to be correlated with harmful effects on corals, given that all indices consider thermal events occurring outside the $1^{\circ}$ interval around the mean SST.

\section{Statistical analysis}

We analyzed overall patterns of disease and/or compromised health condition prevalence by looking at its mean value by region over all years. We also analyzed disease and/or compromised health conditions for individual sampling years. In addition, these patterns were disaggregated at the level of coral families to highlight variability in the prevalence of unhealthy conditions that impact coral assemblages and identify which coral families were most impacted in general.

Preliminary analysis of the relationship between temperature anomalies and disease prevalence involved regressing regional disease prevalence against each of the 6 temperature anomaly metrics (Fig. S1). Disease prevalence was also used as a response variable in regressions with regional coral cover and transect health (see next paragraph).

To test whether temperature anomalies were a significant factor associated with disease prevalence, we analyzed patterns of disease prevalence using Generalized Linear Mixed Models (GLMM). A GLMM (binomial regression with a canonical link function) was fitted for each disease category, with disease prevalence as the response variable, location as a random effect, and other explanatory variables included as fixed effects. Models were fitted using R's library lme4 (Bates et al. 2001, R Development Core Team 2010). Explanatory variables included (1) percent coral cover per transect (LIT), (2) an indicator variable for coral cover over $50 \%$ (UCHC), geographic position of each site using (3) longitude (Long) and (4) latitude (Lat), (5) a rough indicator of transect health defined by the number of different diseases and compromised health conditions occurring concurrently (NSyn), (6) the sampling year, (7) the transect area, (8) coral biodiversity using the Shannon equitability index (Shannon), and 6 SST indices, denoted SST1 to SST6 (as defined above). Explanatory variables $1,3,4,5,6$ and 7 were centered by subtracting the mean to reduce numerical insta- 
bilities. Because of the spatial scale of the explanatory variables, we considered longitude (3), latitude (4), and temperature indices as regional predictors, whereas coral cover (1 and 2), transect area (7), coral biodiversity (8) and transect health (5) were considered to be local predictors. We selected models based on their Akaike's information criterion (AIC) using a top-down strategy. This consists of initially fitting a full model and accepting reduced models (i.e. those obtained by removing covariates) as long as the AIC improved for each simplified model (Diggle et al. 2002). Locality was included as a random effect in all these models, enabling differences at regional scales to be detected.

All SST indices were highly correlated, hence we used a principal component analysis (PCA) to decorrelate them (Table S3 in the supplement) before using them in the GLMM models. All 6 principal components were used for fitting the models, although it is worth noting that the first 2 components (accumulating $97 \%$ of the variation) were strongly determined by SST3 and SST4 (Zuur et al. 2009).

Approximate baseline levels of disease per region with reference disease prevalence values were calculated considering the limits of the lower quartile for the disease prevalence distribution.

\section{RESULTS}

This worldwide survey of coral disease revealed levels of disease prevalence that were higher than expected, with $20.17 \%$ of the reefs surveyed in the Caribbean and $2.68 \%$ of reefs surveyed in the Pacific showing high disease prevalence levels (i.e. annual mean prevalence values greater than $10 \%$ ).

\section{Overall disease patterns}

Our results show significant differences in mean disease prevalence between regions across all disease types and years (Fig. 2a, Figs. S1 to S5 in the supplement). At the regional level, when all sites were aggregated within regions, mean disease prevalence across years varied significantly among regions, with lowest values recorded in Hawaii (NWHI; $0.02 \pm 0.02 \%, \mathrm{n}=81$ ) and highest values in the Mexican Yucatan $(8.30 \pm 0.36 \%)$. For the Pacific regions, regional mean disease prevalence across years in the Philippines $\left(\mathrm{PH}_{i} 4.64 \pm 0.45 \%\right.$, $\mathrm{n}=60$ ) was higher than in 3 regions in the Great Barrier Reef $\left(\mathrm{GBR}_{i} 1.32 \pm 0.09 \%, \mathrm{n}=80\right)$, and both were significantly greater than mean values found for Hawaii (Wilcoxon Mann-Whitney test, $\mathrm{PH}>$ NWHI, $\mathrm{p}<<0.0001$; GBR $>$ NWHI, $\mathrm{p}<<0.0001)$. Due to the lack of data from NWHI, we were unable to evaluate interannual disease prevalence variability.

Globally, the most prevalent disease categories were: the combined category for Caribbean white signs and Indo-Pacific white syndromes (WSS), nonthermal bleached spots (BLS), yellow bands (YB) and dark spots (DS) (Fig. S2). In addition, mean disease

Table 3. Overall disease prevalence differences between Caribbean $(n=863)$ and Pacific sites $(n=224)$ as determined by Wilcoxon Mann-Whitney tests for comparisons between basins. For diseases present only in one basin, the test reports wether the prevalence in the corresponding basin is significantly different from zero. See Table 2 for disease category abbreviations

\begin{tabular}{|c|c|c|c|c|}
\hline Disease & Geographic range & W & $\begin{array}{c}\text { Different prevalence } \\
\text { p }\end{array}$ & $\begin{array}{c}\text { Carribean vs Pacific } \\
\mathrm{p}\end{array}$ \\
\hline ALL & Caribbean \& Pacific & 130158 & $\operatorname{YES}\left(1.110 \times 10^{-15}\right)$ & $\operatorname{GREATER}\left(5.551 \times 10^{-16}\right)$ \\
\hline AtN & Pacific & 100716 & $\operatorname{YES}\left(6.2 \times 10^{-7}\right)$ & $\operatorname{LESS}\left(3.1 \times 10^{-7}\right)$ \\
\hline BBD & Caribbean \& Pacific & 90221 & YES (0.009717) & LESS (0.004859) \\
\hline BLS & Caribbean \& Pacific & 84101.5 & YES (0.0001059) & $\operatorname{LESS}\left(5.297 \times 10^{-5}\right)$ \\
\hline BRB & Pacific & 70766 & $\operatorname{YES}\left(<2.2 \times 10^{-16}\right)$ & $\operatorname{LESS}\left(<2.2 \times 10^{-16}\right)$ \\
\hline $\mathrm{CCI}$ & Caribbean & 107408 & $\operatorname{YES}\left(1.81 \times 10^{-7}\right)$ & GREATER $\left(9.05 \times 10^{-8}\right)$ \\
\hline DS & Caribbean \& Pacific & 145611 & $\operatorname{YES}\left(<2.2 \times 10^{-16}\right)$ & $\operatorname{GREATER}\left(<2.2 \times 10^{-16}\right)$ \\
\hline GA & Caribbean \& Pacific & 83533 & $\operatorname{YES}\left(3.881 \times 10^{-15}\right)$ & $\operatorname{LESS}\left(1.940 \times 10^{-15}\right)$ \\
\hline SEB & Pacific & 66019.5 & $\operatorname{YES}\left(<2.2 \times 10^{-16}\right)$ & $\operatorname{LESS}\left(<2.2 \times 10^{-16}\right)$ \\
\hline TDL & Caribbean & 114800 & $\operatorname{YES}\left(2.641 \times 10^{-12}\right)$ & $\operatorname{GREATER}\left(1.32 \times 10^{-12}\right)$ \\
\hline UWS & Pacific & 84142.5 & $\operatorname{YES}\left(<2.2 \times 10^{-16}\right)$ & $\operatorname{LESS}\left(<2.2 \times 10^{-16}\right)$ \\
\hline WSS & Caribbean \& Pacific & 114042 & YES $\left(1.742 \times 10^{-5}\right)$ & GREATER $\left(8.71 \times 10^{-6}\right)$ \\
\hline YB & Caribbean $^{\mathrm{a}}$ & 145040 & $\operatorname{YES}\left(<2.2 \times 10^{-16}\right)$ & $\operatorname{GREATER}\left(<2.2 \times 10^{-16}\right)$ \\
\hline
\end{tabular}



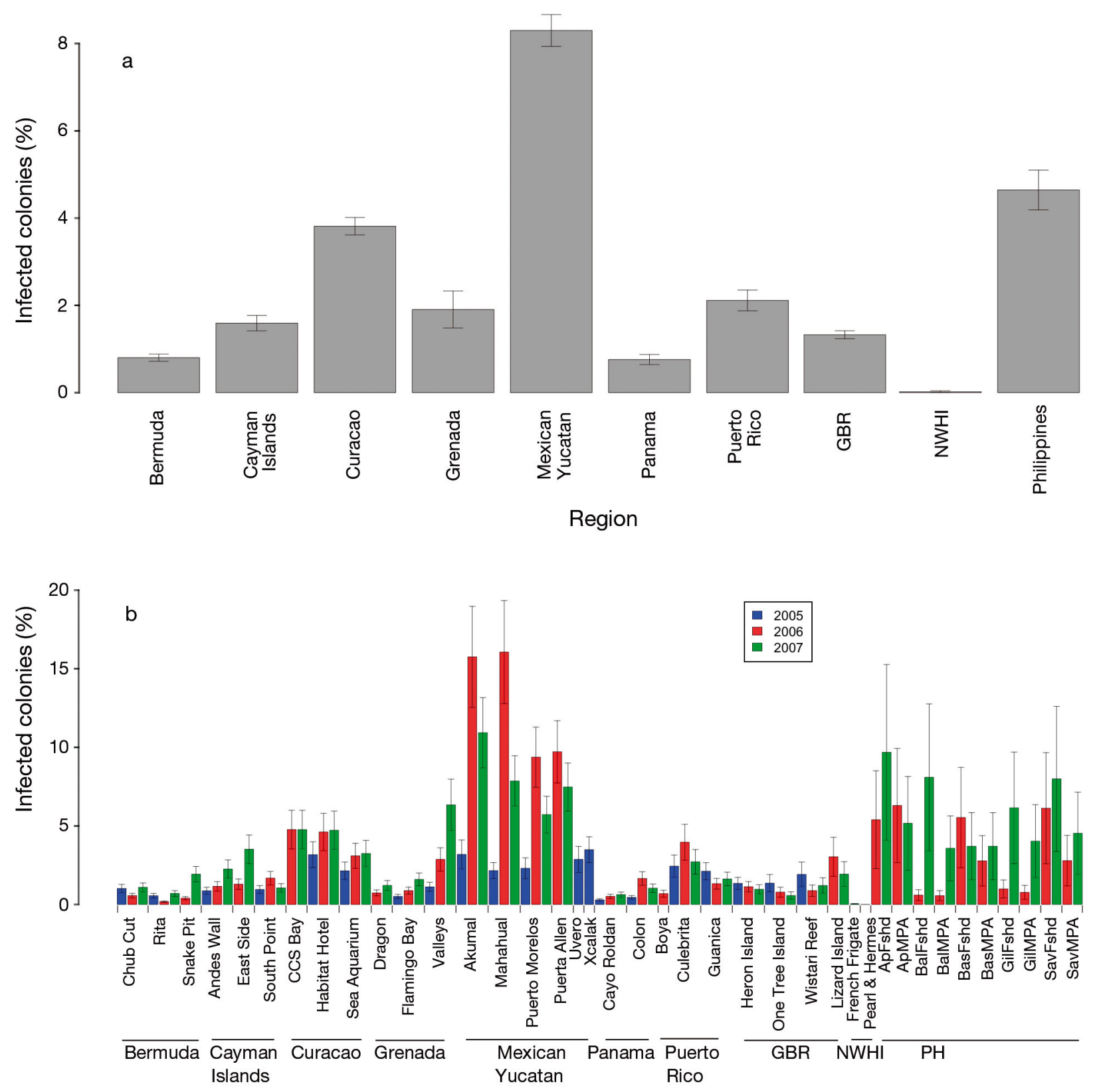

Fig. 2. (a) Mean ( \pm SE) prevalence for the different geographic regions (aggregating all diseases and years 2005, 2006 and 2007). (b) Mean ( \pm SE) disease prevalence for all diseases by year and location (Table 1). NWHI: Northwestern Hawaiian Islands; PH: Philippines; GBR: Great Barrier Reef

prevalence across years for individual diseases was highly variable between regions. Three of the diseases, black band disease (BBD), BLS and growth anomalies (GA), that were present in all the 10 regions, were more prevalent at the Pacific sites (Table 3). WSS and DS together with diseases confined to the Caribbean, Caribbean ciliate infections (CCI), thin dark line (TDL) and YB, drove the higher prevalence levels reported for that basin (Table 3).

\section{Diseases across coral families and regions}

Although the diseases identified are considered opportunistic (Carpenter et al. 2008), some coral families showed extreme vulnerability (Fig. 3). Differences in overall mean disease prevalence were driven in part by differences in the degree to which different coral families were affected by disease (Fig. 3). For example, coral assemblages in the Pacific, which were more diverse (146 genera vs. 61 in the Caribbean), ap- 


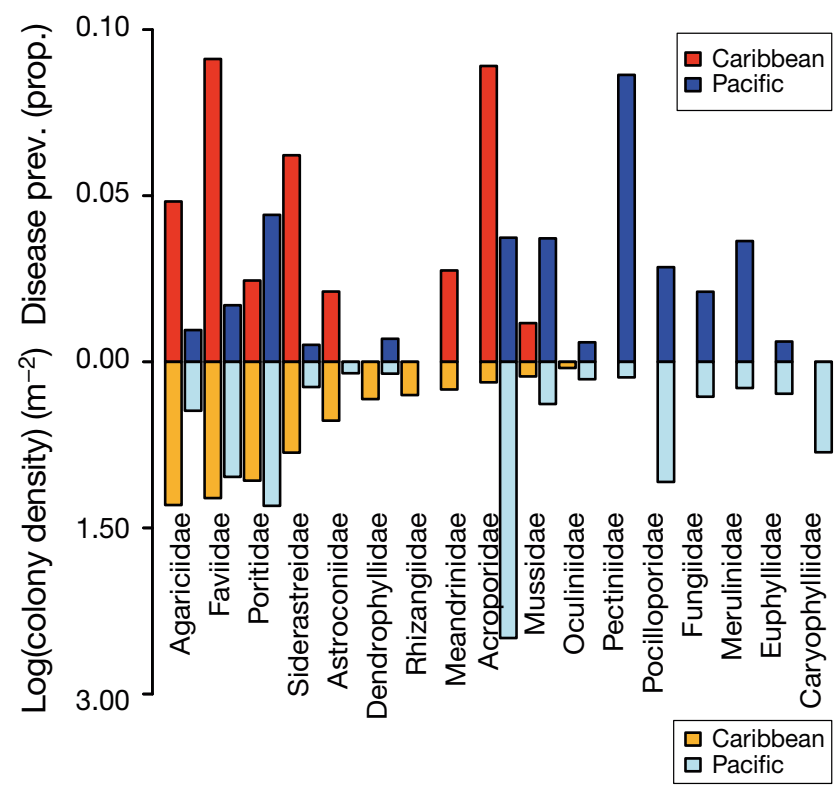

Fig. 3. Upper bars: Mean disease prevalence by coral family (all years) for sites in the Caribbean (red) and Pacific (blue). Lower bars: Mean density of each coral family (no. of colonies $\mathrm{m}^{-2}$ ) over all years for the sites in the Caribbean (orange) and Pacific (light blue). Families are ordered by density in the Caribbean. Vulnerability and abundance of faviids and siderastreids seems to drive high disease prevalence in the Caribbean (Table 3)

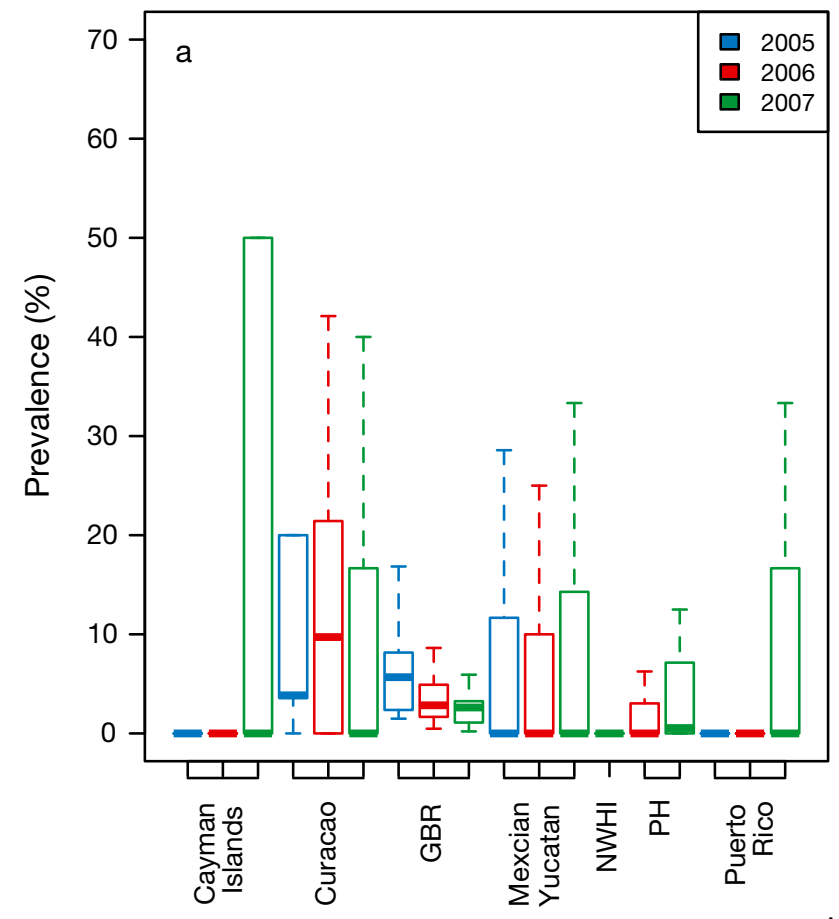

peared to have a lower disease burden than those in the Caribbean. Of the 17 families observed globally, 4 -Acroporidae, Faviidae, Siderastreidae and Agariciidae-stand out as having higher disease prevalence in the Caribbean regions than in the Pacific, with at least 2-fold higher disease prevalence than other families in the Caribbean (Fig. 3). Pectiniidae colonies in the Pacific also appear to be highly vulnerable to disease. Despite these overall levels of infection, there was high spatial and temporal variability in disease prevalence and other unhealthy conditions across all families, in particular for the 2 families with higher global disease burden (Fig. 4).

The high prevalence in the Acroporidae, the fourth most abundant family in these data (Table S4 in the supplement) including the threatened species, Acropora palmata and A. cervicornis, is of particular concern. Globally averaged, this family shows comprised health conditions prevalence of around $4 \%$ and a disease prevalence of $6 \%$ (Table 4 ). At the regional scale mean acroporid disease prevalence across years exceeds $25 \%$ in locations at Cayman Islands, Curacao, PH and Puerto Rico (Table S1). The most prevalent diseases for the Acroporidae, on a global scale, were WSS, BLS and CCI (Table 4), with sites in the Caribbean showing the highest prevalence

\section{Location}

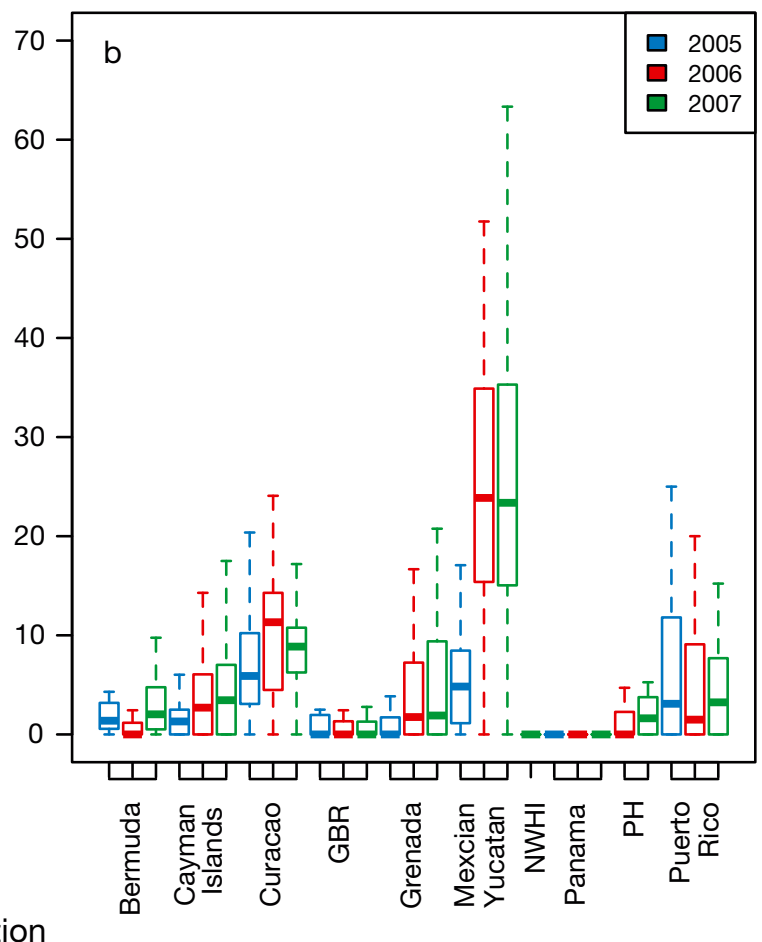

Fig. 4. Box plots of coral disease prevalence by location (Table 1) and year for 2 indicator families (i.e. those most infected in Fig. 3): (a) acroporids and (b) faviids. Clear regional and temporal variability in disease prevalence suggests that vulnerability might be affected by local factors 
Table 4. Inter-annual global mean prevalence of each disease for 2 coral families, the acroporids and faviids. See Table 2 for disease category abbreviations

\begin{tabular}{|lll|}
\hline Category & \multicolumn{2}{c|}{ Global prevalence (\%) } \\
& Acroporidae & \multicolumn{1}{c|}{ Faviidae } \\
\hline AtN & 0.06963642 & 0.03122199 \\
BBD & 0.0686702 & 0.232346 \\
BLS & 0.6885817 & 2.172486 \\
BRB & 0.1952583 & 0.000000 \\
CCI & 0.5108198 & 0.2554249 \\
DS & 0.0002251811 & 0.3332645 \\
GA & 0.04537656 & 0.06826502 \\
SEB & 0.2921922 & 0.0087303 \\
TDL & 0.000000 & 0.99426 \\
UWS & 0.01301614 & 0.004189359 \\
WSS & 4.789515 & 1.77669 \\
YB & 3.143572 & 3.143572 \\
CHC & 4.022901 & 5.35459 \\
All diseases & 6.641155 & 8.090702 \\
All unhealthy & 10.57073 & 13.39787 \\
& & \\
\hline
\end{tabular}

(Curacao, Cayman Islands and Mexican Yucatan in decreasing order, results not shown). The high prevalence of $\mathrm{CCI}$, the third most prevalent disease category among the acroporids (but fifth globally, Fig. S2), suggests a high vulnerability of acroporids to this disease.

Prevalence of infectious diseases and $\mathrm{CHC}$ for the faviids, the most abundant coral family in the database (Table S4), reached 5 and $8 \%$ respectively (Table 4). At the regional scale, a few Caribbean sites showed disease prevalence over $25 \%$. Globally, the 3 main diseases of faviids were YB, BLS and WSS (Table 4), with greater prevalence at Caribbean sites for all 3 diseases (YB and BLS were most common diseases in Mexican Yucatan, and WSS in Puerto Rico). The principal disease in the Caribbean was YB that affects 3 Montastraea species, Montastraea annularis, M. franksi and M. faveolata.

\section{Disease prevalence and temperature anomalies}

Regional disease prevalence varies with 2 of the thermal indices (see Fig. S1 for plots against each index and year), which account for the annual accumulation of extreme warm (SST3) and cold (SST4) thermal stress (Fig. 5). These 2 indices were chosen because they are the most important components in the first 2 PCA components (that account for $97 \%$ of the variability) and represent the accumulation of thermal stress. Although variability is high, overall regional disease prevalence increased with the magnitude of the accumulated thermal stress.

\section{Disease prevalence and other observed variables}

Regional disease prevalence also varies with 2 transect level factors, Shannon equitability and the number of co-occurring unhealthy conditions (Fig. 6). In agreement with theoretical predictions that disease prevalence should vary with host biodiversity, Fig. 6a shows increasing levels of disease prevalence with reduced biodiversity of coral reefs. Fig. $6 \mathrm{~b}$ shows increasing levels of disease prevalence with the number of unhealthy syndromes (infectious disease and compromised health combined).

The best of the proposed models, when all diseases are included as response variable, shows a significant role of the physical characteristics of each tran-
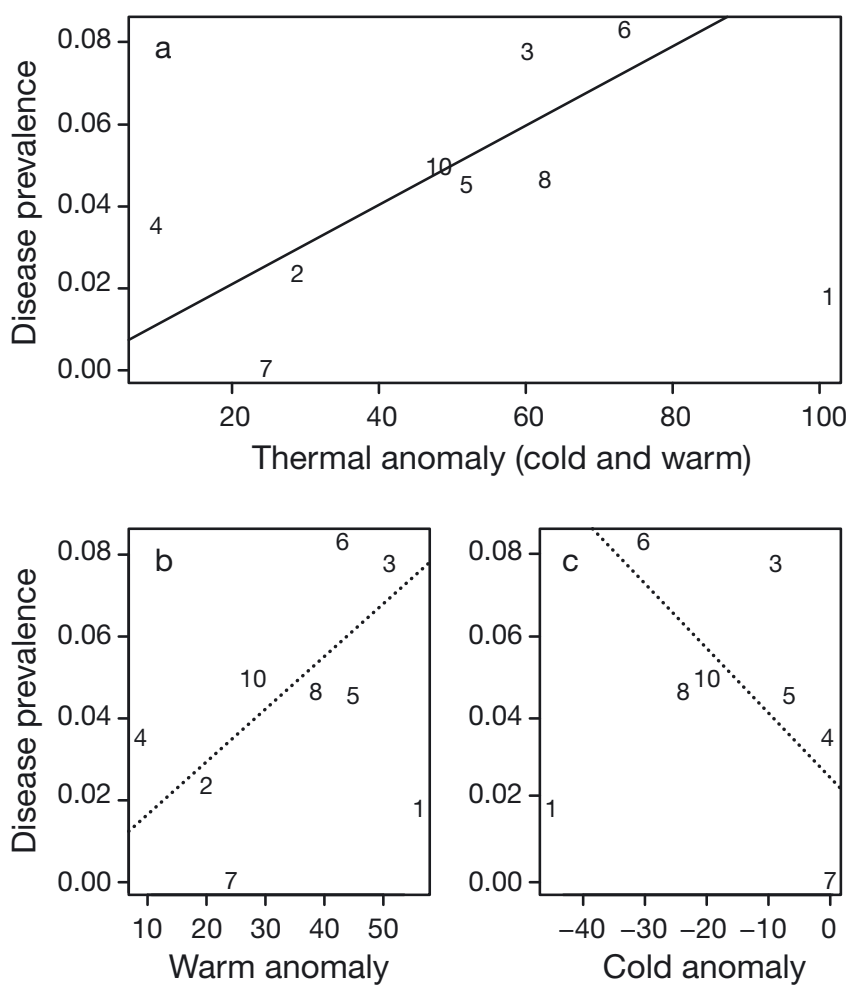

Fig. 5. Regional mean coral disease prevalence by proportion of corals with disease and temperature indices showing (line) significant linear regression fit. Numbers correspond to regions. See Table 1 for region descriptions. (a) Disease prevalence regressed against accumulated thermal stress, which was determined by adding SST3, the summation of sea surface temperatures over the mean plus $1^{\circ} \mathrm{C}$, with SST4, the summation of sea surface temperatures under the mean minus $1{ }^{\circ} \mathrm{C}$ (adjusted $\mathrm{R}^{2}=0.5478, \mathrm{p}=0.0217$ ). (b) Disease prevalence against warm anomaly (adjusted $R^{2}=0.38$, $\mathrm{p}=0.0596$ ). (c) Disease prevalence against cold anomaly (adjusted $\mathrm{R}^{2}=0.32, \mathrm{p}=0.0805$ ). Data corresponding to Panama were not available to be included in this analysis. 1: Bermuda, 2: Cayman Islands, 3: Curacao, 4: Great Barrier Reef, 5: Grenada, 6: Mexican Yucatan, 7: Northwestern Hawaiian Islands, 8: Philippines, 9: Panama, 10: Puerto Rico 


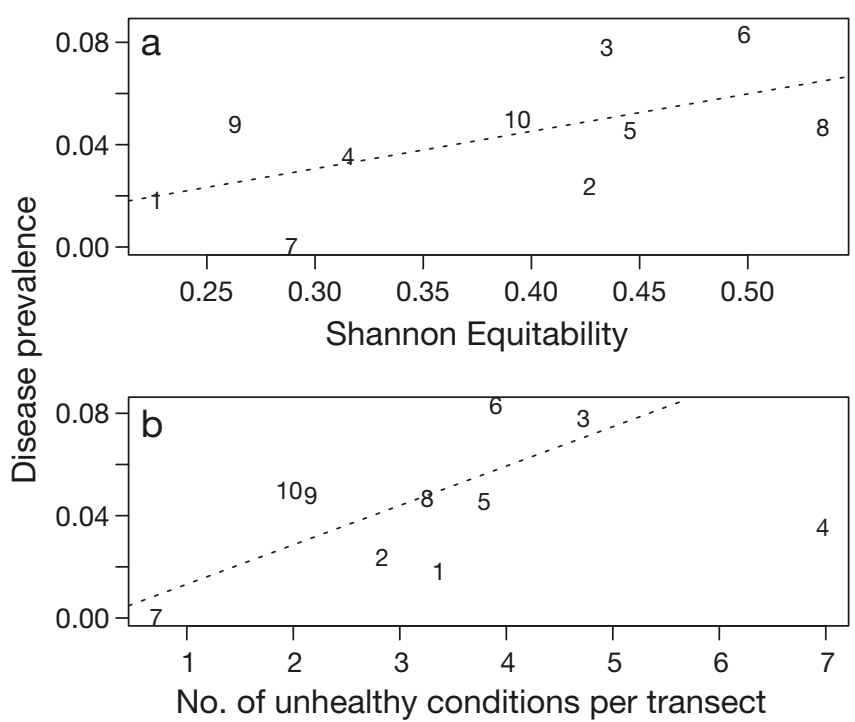

Fig. 6. Regional mean coral disease prevalence and local factors. (a) Disease prevalence regressed against the Shannon Equitability Index showing a (dotted line) marginally significant linear regression (adjusted $\mathrm{R}^{2}=0.27, \mathrm{p}=0.0672$ ) . Evenness (or minimum biodiversity) is represented by 1 in the Shannon Equitability Index and 0 represents the maximum observed biodiversity. (b) Disease prevalence regressed against the number of distinct unhealthy syndromes observed per transect (adjusted $R^{2}=0.41, p=0.0369$ after outlier elimination). Regions are: 1: Bermuda, 2: Cayman Islands, 3: Curacao, 4: Great Barrier Reef, 5; Grenada, 6: Mexican Yucatan, 7: Northwestern Hawaiian Islands, 8: Philippines, 9: Panama, 10: Puerto Rico

sect (latitude, longitude and area) together with the number of syndromes present per transect. The influences of 1 component of the thermal anomalies (PC4 that negatively corresponds to maximum temperatures), year, latitude, longitude and area also have a significant effect on disease prevalence. Random effects displayed larger variability for diversity (Shannon) and sampling year (Table 6).

When diseases and compromised health conditions are modeled individually, the importance of the predictors varies (Table 7). For example, BRB and YB prevalence appear as positively correlated with some components of the thermal anomalies (PC5, and PC2, PC5 and PC6, respectively). BBD, CCI and Ulcerative White Signs (UWS) disease prevalence are negatively related with components PC5, PC3 and PC1 respectively. BLS, DS and WSS showed both positive and negative relationships. Similarly, the set of compromised health conditions have positive and negative relationships with temperature. Finally, Atramentous Necrosis (AtN), GA, Skeleton Eroding Band (SEB) and TDL do not vary with thermal anomalies in this data set.
Table 5. Estimated mean regional disease baseline. Approximate baseline levels were calculated considering the limits of the lower quartile for disease prevalence distribution per region

\begin{tabular}{|lc|}
\hline Region & Baseline (\%) \\
\hline Caribbean & \\
Bermuda & 0.3914 \\
Cayman Islands & 0.5871 \\
Curacao & 3.9139 \\
Grenada & 0.7828 \\
Mexican Yucatan & 4.1096 \\
Panama & 1.3699 \\
Puerto Rico & 1.7613 \\
Pacific & \\
Great Barrier Reef & 1.5656 \\
North West Hawaii & 0.000000 \\
Philippines & 2.1526 \\
Caribbean \& Pacific, combined & 1.3699 \\
\hline
\end{tabular}

Table 6. Best regression fit from the generalized linear mixed model that considers the effects of environmental variables $(n=429)$ on prevalence of all diseases. Disease prevalence was regressed against 7 variables that were centered by subtracting the mean to reduce numerical instabilities, coral cover (LIT), equitability (Shannon), sampling year, transect area, location latitude and longitude, number of syndromes per transect (NSyn), and 1 non-centered variable, a high cover indicator variable (UCHC), and the principal components of thermal anomaly indices (PC1 to PC6). Random effects displayed larger variability for equitability (Shannon), sampling year, no. of syndromes and coral cover; other random effects are negligible. All the significant fixed effects are shown in the fixed effect section (no. of groups $=16$ )

\begin{tabular}{|lccc|}
\hline Groups & \multicolumn{3}{c}{ Random effects } \\
& Variable & Variance & SD \\
\hline Transect locality & LIT & 0.00017 & 0.013 \\
Transect locality & Shannon & 6.58 & 2.57 \\
Transect locality & Sampling year & 1.33 & 1.15 \\
Transect locality & Transect area & $2.26 \times 10^{-4}$ & $1.50 \times 10^{-7}$ \\
Transect locality & Locality Lat & 0 & 0 \\
Transect locality & Locality Long & 0 & 0 \\
Transect locality & NSyn & 0.075 & 0.27 \\
Transect locality & UCHC & 0.041 & 0.20 \\
& & & \\
& & Fixed effects & \\
& Estimate & SE & Pr $(>\mid \mathrm{zl})$ \\
\hline & 0.013 & 0.007 & 0.062 \\
& & 0.023 & 0.0052 \\
Transect area & -0.064 & 0.0060 & 0.00041 \\
Transect latitude & -0.021 & 0.076 & $<0.0001$ \\
Transect longitude & -0.31 & 0.34 & $<<0.0001$ \\
Transect NSyn & 0.50 & 0.0001 \\
Transect Year $\times$ PC4 & 5.50 & $<<0.0001$ \\
Transect Area $\times$ PC4 & -0.079 & 0.011 & $<<0.0001$ \\
Transect Lat $\times$ PC4 & -0.74 & 0.087 & $<<0.0001$ \\
Transect Long $\times$ PC4 & -0.095 & 0.012 & \\
\hline
\end{tabular}


Table 7. Significant factors in the best regression models for each disease individually. Factors vary in significance depending on the disease that is modeled in the regression. The rows with the principal component analysis (PCA) corresponding to the thermal anomaly indices include more than one factor (for example in Table 6, there is an interaction of PC4 with 4 other predictor variables). Hence, PCA indices might change either the slope or intercept of the regression line. Slopes and intercepts with different signs are coded as ' $+/{ }^{\prime}$ '; symbols correspond to the sign of all factors otherwise. See Table 2 for disease category abbreviations. LIT: coral cover, NSyn: no. of syndromes, UCHC: high cover indicator variable

\begin{tabular}{|c|c|c|c|c|c|c|c|c|c|c|c|c|c|}
\hline & AtN & BBD & BLS & $\mathrm{BRB}$ & $\mathrm{CCI}$ & $\mathrm{CHC}$ & DS & GA & SEB & TDL & UWS & WSS & YB \\
\hline Intercept & & -6.71 & & -19.4 & -14.5 & 3.41 & -4.43 & -9.21 & & -18.0 & -14.57 & -6.01 & -8.43 \\
\hline LIT & & & & & & & & -0.04 & -0.02 & & & & 0.03 \\
\hline Shannon & & -8.09 & & & & 2.22 & 5.35 & & -1.51 & & & & \\
\hline Year & & -0.77 & & & & & 0.19 & & -3.14 & & & 0.54 & 0.96 \\
\hline Area & & & & & & -0.24 & 0.09 & & & & & & \\
\hline NSyn & & 0.53 & & & & 0.30 & 0.27 & 0.57 & 0.08 & & & 0.44 & 0.27 \\
\hline UCHC & & 1.05 & & & & & & 1.55 & 0.25 & & & & -0.57 \\
\hline $\mathrm{PC} 1$ & & & + & & & & $+/-$ & & & & - & & \\
\hline PC2 & & & & & & & & & & & & & + \\
\hline PC3 & & & - & & - & & & & & & & & \\
\hline $\mathrm{PC} 4$ & & & + & & & $+/-$ & & & & & & $+/-$ & \\
\hline PC5 & & - & + & + & & & & & & & & & + \\
\hline PC6 & & & + & & & & & & & & & & + \\
\hline Random & $\mathrm{S}$ & $\mathrm{S}$ & $\mathrm{S}$ & $\mathrm{S}$ & $\mathrm{S}$ & $\mathrm{C}$ & $\mathrm{S}$ & $\mathrm{S}$ & $\mathrm{S}$ & S & $\mathrm{S}$ & $\mathrm{C}$ & $\mathrm{C}$ \\
\hline \multicolumn{14}{|c|}{ Codification for random effects } \\
\hline \multicolumn{14}{|c|}{ S: (1। Transect Locality) } \\
\hline \multicolumn{14}{|c|}{$\begin{array}{l}\text { M: (LIT I Transect Locality) + (Shannon I Transect Locality) + (Sampling year I Transect Locality) + (Transect Area I } \\
\text { Transect Locality) }\end{array}$} \\
\hline \multicolumn{14}{|c|}{$\begin{array}{l}\text { C: }(1 \text { I Transect.Locality })+(0+\text { LIT I Transect Locality })+(0+\text { Shannon I Transect Locality })+(0+\text { Sampling year I Transect } \\
\text { Locality })+(0+\text { Transect Area I Transect Locality })+(0+\text { Locality Lat I Transect Locality })+(0+\text { Locality Long I Transect } \\
\text { Locality })+(0+\text { NSyn I Transect Locality })+(0+\text { UCHC I Transect Locality })\end{array}$} \\
\hline
\end{tabular}

\section{DISCUSSION}

Our surveys reveal high variability in both local and regional mean disease prevalence, with particularly high levels for the sites in the Mexican Yucatan (with transects that show disease prevalence ranging from $1.9 \%$ in Puerto Morelos in 2005, up to $30 \%$ in Akumal in 2006), Philippines and Curacao (Fig. 2). Although more sites need to be sampled in the Pacific to produce a comprehensive picture, disease prevalence is high in more Caribbean than Pacific sites, and previous work suggests this is a general pattern. Disease prevalence exceeded $10 \%$ in $20 \%$ of Caribbean transects and in only $2.7 \%$ of Pacific surveys. The higher prevalence of diseases in the Caribbean is expected, based on the frequency of reported disease outbreaks in the Caribbean and the relative lack of reported major coral disease outbreaks in the Pacific. One exception is the recent repots on white syndrome outbreak in Australia in 2002 (Maynard et al. 2010). We hypothesize that the higher level of disease in the Caribbean is partly a consequence of long-term thermal and anthropogenic stress in this region relative to the Pacific (Barton \& Casey 2005). This is particularly important given that accumulation of both warm and cold thermal anomalies (indices SST3 and SST4) are significant predictors of disease prevalence, even at a regional level that encompasses significant landscape heterogeneity. However, this data set highlights the importance of monitoring additional Pacific sites before developing more comprehensive hypotheses about causal factors.

Local factors that we know influence disease impacts are host density and differences in host susceptibility (Figs. $3 \& 4$, Table 7). The regional variation in disease prevalence among the acroporids was particularly striking, with disease prevalence in the Caribbean close to $10 \%$ (where the family includes only 3 species, Acropora palmata, A. cervicornis and A. prolifera, that are already in low abundance from previous disease outbreaks), and prevalence was only slightly above the mean in the Pacific basin (where there can be more than 70 acroporid species co-occurring and where they often are spatially dominant). Temporal variability in the role of local factors and other factors (such as previous disease outbreaks), coupled with variation caused by climate, could drive highly non-linear dynamics, with unpredictable tipping points (i.e. those that could shift 
ecosystems between equilibria). For example, the increase in disease prevalence observed in several sites in the Caribbean in 2006 (Tables S1 \& S2) may have caused coral mortality and algae proliferation, changing the dynamics of the ecosystem at particular locations (Carpenter et al. 2008). Such an increase in disease prevalence followed a massive thermal bleaching event in 2005 that may have simultaneously compromised host immunity and increased pathogen virulence (Cróquer \& Weil 2009, Harvell et al. 2009, Miller et al. 2009, Muller \& van Woesik 2009).

The few studies linking levels of disease prevalence with environmental drivers have shown that, for some syndromes, warmer-than-normal temperatures are associated with increased disease. Warm temperatures could simultaneously increase pathogen growth and virulence and compromise immunity of coral hosts (Barton \& Casey 2005, Bruno \& Selig 2007, Bruno et al. 2007, Harvell et al. 2009, Weil \& Cróquer 2009, Muller \& van Woesik 2009). Additionally, although cold temperature might be beneficial for host recovery by reducing pathogen growth rate (e.g. BBD and YB) (Harvell et al. 2009, Sato et al. 2009), the effect of cold temperatures is still unpredictable since they may stress the coral host and facilitate disease. Increases in disease prevalence and pathogen virulence are expected from warm temperatures in either summer or winter. For example, the oyster parasite Perkinsus marinus was limited by cold winters until winter warming events in the 1990s allowed a parasite range expansion northward (Ford 1996). The effects of cold thermal stress are less frequently studied and more difficult to predict because they may compromise both host and pathogen (Laboy-Nieves et al. 2001, Chen et al. 2009, Heron et al. 2010). A striking result from our study that has not been previously reported is the association of some disease increases with cold temperature anomalies (see BLS, DS and YB in Table 7).

Given inherent variability in community composition between reefs and oceans, weather and climate variation, and local impacts on water quality (Haapkylä et al. 2011), a single baseline level of disease that would represent 'healthy' conditions is unlikely to exist, even at the scale of individual reefs. Estimating current baselines of disease prevalence for apparently healthy reefs is challenging given the small number of sites for which there are comparable data and the redefinition of healthy conditions (i.e. 'baseline shifting') (Pauly 1995). Standardized survey methods and permanent monitoring sites could provide enough information to determine interannual variability in disease prevalence, if climate change was slow enough. We can, however, hypothesize that sites with levels of disease below 3 to $5 \%$ (based on the lower $25 \%$ of the distribution of mean disease prevalence) are a first approximation to real baseline levels. Using regional levels of disease to define disease prevalence ranges, the results suggest a range of baseline disease prevalence (community level) from $0.3 \%$ (Bermuda) to $4 \%$ (Mexican Yucatan) for the sites in the Caribbean and values from nearly 0 (NHWI) to $1.7 \%(\mathrm{PH})$ for those from the Pacific (Table 5). These approximate values could be useful as a reference point from which to measure future change. From these approximated baseline estimates, reefs in the Northwest Hawaiian Islands, with very low levels of coral disease, clearly seem to be one of the few locations in the world showing a baseline of disease prevalence that might represent historical levels on pristine reefs. Continuous sampling of those sites could provide better support for these ideas. Dinsdale (2008) reported 2.5 to $6.2 \%$ from pristine locations in the Pacific, and Haapkylä et al. (2011), 1\% in Wakitobi, Indonesia (also see Sandin et al. 2008). More recent reports of disease prevalence up to $7.09 \%$ in the Main Hawaiian Islands are in strong contrast to the very low levels in the NWHI.

The standardized methods used in this survey confirm that disease prevalence was extremely high during our study from 2005 to 2007 in the Caribbean (Figs. 2 \& S3 to S7), with unusually high levels in faviids (Fig. 4). Although levels were lower most years and locations in the Pacific (Figs. 2 \& S3 to S7), levels of disease were high for acroporids in Australia in 2005 and 2007 in the Philippines (Fig. 4). A closer examination of disease prevalence by year and site shows its high variability (Fig. 2b), with high disease prevalence levels in the Mexican Yucatan sites in the Caribbean and many sites in the Philippines. There is a strong increase in disease prevalence in 2006 in Mexico, which is likely a response to a large temperature anomaly from 2005, centered in that part of the Caribbean. Similarly, the increase in the Philippines in 2007 may be related with the temperature anomaly from 2006 in the Pacific (www.osdpd.noaa.gov). Our results suggest that, in the Caribbean, the common reef-building coral families Faviidae, Acroporidae, Siderastreidae and Agariciidae were the most affected by several of the described diseases presented here (Figs. 3, S1 \& S2, Table 4). The Acroporidae is also one of the most affected families on the Pacific reefs surveyed, but the specific disease impacts are more equitably spread among families. This study also confirms a role for temperature anom- 
alies, with higher levels of disease in locations exposed to higher thermal anomalies, both warm and cold. With the disease prevalence levels reported here for representative sites, detecting future changes in disease levels and planning studies to elucidate the roles of climate and other human-induced pressures in coral disease outbreaks will now be possible.

Acknowledgements. We acknowledge fieldwork by R. E. Rodríguez-Martínez, J. Andras, M. A. Maldonado and L. Vázquez, I. Urreiztieta and J. Locke. We are grateful for funding for fieldwork from the Coral Reef Targeted Research Program and for analysis from Atkinson Center for a Sustainable Future. We thank the logistical support provided by the Department of Marine Sciences, University of Puerto Rico, S. Pointek and the Curaçao Sea Aquarium, C. Morrall (Department of Biology, University of Grenada) and Devotion 2 Ocean dive shop in Grenada, J. Ward, K. Coates, S. Manuel and Captain A. Nash and the Department of Conservation Services in Bermuda, H. Guzmán, C. Guevara and the Smithsonian Tropical Research Institute in Panamá, and G. Fairbanks, C. McCoy and the Department of the Environment in Grand Cayman.

\section{LITERATURE CITED}

Aeby GS (2006) Baseline levels of coral disease in the Northwestern Hawaiian Islands. Atoll Res Bull 543:471-488

Aeby GS, Williams GJ, Franklin EC, Haapkyla J, and others (2011) Growth anomalies on the coral genera Acropora and Porites are strongly associated with host density and human population size across the Indo-Pacific. PLoS ONE 6:e16887

Aronson RB, Precht WF (2001) White-band disease and the changing face of Caribbean coral reefs. Hydrobiologia 460:25-38

Baker DM, MacAvoy SE, Kim K (2007) Relationship between water quality, $\delta^{15} \mathrm{~N}$, and aspergillosis of Caribbean sea fan corals. Mar Ecol Prog Ser 343:123-130

Barton AD, Casey KS (2005) Climatological context for large-scale coral bleaching. Coral Reefs 24:536-554

Bates D, Maechler M, Bolker BM (2011) Linear mixedeffects models using S4 classes. cran.r-project.org/web/ packages/lme4//index.html

Beeden R, Willis BL, Raymundo LJ, Page CA, Weil E (2008) Underwater cards for assessing coral health on IndoPacific reefs. Global Environment Facility Coral Reef Targeted Research Program, St. Lucia

Bruno JF, Selig ER (2007) Regional decline of coral cover in the Indo-Pacific: timing, extent, and subregional comparisons. PLoS ONE 2:e711

Bruno JF, Petes LE, Harvell CD, Hettinger A (2003) Nutrient enrichment can increase the severity of coral diseases. Ecol Lett 6:1056-1061

Bruno JF, Selig ER, Casey KS, Page CA, Willis BL, Harvell CD, Sweatman H, Melendy AM (2007) Thermal stress and coral cover as drivers of coral disease outbreaks. PLoS Biol 5:e124

> Carpenter KE, Abrar M, Aeby G, Aronson RB and others (2008) One-third of reef-building corals face elevated extinction risk from climate change and local impacts. Science 321:560-563

Chen T, Yu K, Shi Q, Li S and others (2009) Twenty-five years of change in scleractinian coral communities of Daya Bay (northern South China Sea) and its response to the 2008 AD extreme cold climate event. Chin Sci Bull 54:2107-2117

Cróquer A, Weil E (2009) Changes in Caribbean coral disease prevalence after the 2005 bleaching event. Dis Aquat Org 87:33-43

Diggle PJ, Heagerty PJ, Liang KY, Zeger SL (2002) Analysis of longitudinal data, 2nd edn. Oxford University Press, Oxford

Dinsdale EA, Pantos O, Smriga S, Edwards RA and others (2008) Microbial ecology of four coral atolls in the Northern Line Islands. PloS ONE 3:e1584

Ford SE (1996) Range extension by the oyster parasite Perkinsus marinus into the northeastern United States: response to climate change? J Shellfish Res 15:45-56

Garren M, Raymundo L, Guest J, Harvell CD, Azam F (2009) Resilience of coral-associated bacterial communities exposed to fish farm effluent. PLoS ONE 4:e7319

Haapkylä J, Unsworth RKF, Flavell M, Bourne DG, Schaffelke B, Willis BL (2011) Seasonal rainfall and runoff promote coral disease on an inshore reef. PLoS ONE 6: e16893

Harvell CD, Jordán-Dahlgren E, Merkel SE, Rosenburg E and others (2007) Coral disease, environmental drivers, and the balance between coral and microbial associates. Oceanography 20:172-195

Harvell CD, Altizer S, Cattadori IM, Harrington L, Weil E (2009) Climate change and wildlife diseases: When does the host matter the most? Ecology 90:912-920

Heron SF, Willis BL, Skirving WJ, Eakin CM, Page CA, Miller IR (2010) Summer hot snaps and winter conditions: modelling white syndrome outbreaks on Great Barrier Reef corals. PLoS ONE 5:e12210

Hoegh-Guldberg O, Mumby PJ, Hooten AJ, Steneck RS and others (2007) Coral reefs under rapid climate change and ocean acidification. Science 318:1737-1742

Hughes TP (1994) Catastrophes, phase shifts, and largescale degradation of a Caribbean coral reef. Science 265: 1547-1551

Jordán-Dahlgren E, Maldonado MA, Rodríguez-Martínez RE (2005) Diseases and partial mortality in Montastraea annularis species complex in reefs with differing environmental conditions (NW Caribbean and Gulf of México). Dis Aquat Org 63:3-12

Kilpatrick KA, Podestá GP, Evans R (2001) Overview of the NOAA/NASA advanced very high resolution radiometer Pathfinder algorithm for sea surface temperature and associated matchup database. J Geophys Res 106(C5): 9179-9197

Laboy-Nieves EN, Klein E, Conde JE, Losada F, Cruz JJ, Bone D. (2001). Mass mortality of tropical marine communities in Morrocoy, Venezuela. Bull Mar Sci 68: 163-179

Maynard JA, Turner PJ, Anthony KRN, Baird AH and others (2008). ReefTemp: an interactive monitoring system for coral bleaching using high-resolution SST and improved stress predictors. Geophys Res Lett 35:L05603. doi:10. 1007/s00338-010-0708-0

Maynard JA, Anthony KRN, Harvell CD, Burgman MA and others (2010) Predicting outbreaks of a climate-driven 
coral disease in the Great Barrier Reef. Coral Reefs 30: 485-495

Maynard JA, Anthony KRN, Harvell CD, Burgman MA and others (2011) Predicting outbreaks of a climate-driven coral disease in the Great Barrier Reef. Coral Reefs 30: 485-495

McClanahan TR (2004) Coral bleaching, diseases and mortality in the western Indian Ocean. In: Rosenberg E, Loya Y (eds) Coral health and disease. Springer-Verlag, Berlin, p 157-176

Miller J, Waara R, Muller EM, Rogers C (2006) Coral bleaching and disease combine to cause extensive mortality on reefs in US Virgin Islands. Coral Reefs 25:418

Miller J, Muller EM, Rogers C, Waara R, Atkinson A, Whelan KRT, Patterson M, Witcher B (2009) Coral disease following massive bleaching in 2005 causes $60 \%$ decline in coral cover on reefs in the US Virgin Islands. Coral Reefs 28:925-937

Montebon ARF (1993) Use of the line intercept technique to determine trends in benthic cover. In: Richmond RH (ed) Proc 7th Int Coral Reef Symp, Vol 1. University of Guam Press, UOG Station, p 151-155

Muller EM, van Woesik R (2009) Shading reduces coraldisease progression. Coral Reefs 28:757-760

Mydlarz LD, Couch CS, Weil E, Smith G, Harvell CD (2009) Immune defenses of healthy, bleached and diseased Montastraea faveolata during a natural bleaching event. Dis Aquat Org 87:67-78

Myers RL, Raymundo LJ (2009) Coral disease in Micronesian reefs: a link between disease prevalence and host abundance. Dis Aquat Org 87:97-104

Pauly D (1995) Anecdotes and the shifting baseline syndrome of fisheries. Trends Ecology Evol 10:430

R Development Core Team (2010) R: a language and environment for statistical computing. R Foundation for Statistical Computing, Vienna

Raymundo LJ, Rosell KB, Reboton CT, Kaczmarsky L (2005) Coral diseases on Philippine reefs: genus Porites is a dominant host. Dis Aquat Org 64:181-191

Raymundo LJ, Couch CS, Harvell CD (2008) Coral disease

Editorial responsibility: Garriet Smith,

South Carolina, USA handbook guidelines for assessment, monitoring \& management. Currie Communications, Melbourne, p 124

Richardson LL (1998) Coral diseases: what is really known? Trends Ecol Evol 13:438-443

> Rogers C (2009) Coral bleaching and disease should not be underestimated as causes of Caribbean coral reef decline. Proc R Soc Lond B Biol Sci 276:197-198

Sandin SA, Smith JE, DeMartini EE, Dinsdale EA and others (2008) Baselines and degradation of coral reefs in the Northern Line Islands. PloS ONE 3:e1548

Sato Y, Bourne DG, Willis BL (2009) Dynamics of seasonal outbreaks of black band disease in an assemblage of Montipora species at Pelorus Island (Great Barrier Reef, Australia). Proc R Soc Lond B Biol Sci 276:2795-2803

Sutherland KP, Ritchie KB (2004) White pox disease of the Caribbean elkhorn coral, Acropora palmata. In: Rosenberg E, Loya Y (eds) Coral health and disease. SpringerVerlag, Berlin, p 289-297

Voss JD, Richardson LL (2006) Nutrient enrichment enhances black band disease progression in corals. Coral Reefs 25:569-576

Weil E (2004) Coral reef diseases in the wider Caribbean. In: Rosenberg E, Loya Y (eds) Coral health and disease. Springer-Verlag, Berlin, p 35-68

> Weil E, Smith G, Gil-Agudelo DL (2006) Status and progress in coral reef disease research. Dis Aquat Org 69:1-7

> Weil E, Cróquer A (2009) Spatial variability in distribution and prevalence of Caribbean scleractinian coral and octocoral diseases. I. Community-level analysis. Dis Aquat Org 83:195-208

Weil E, Hooten AJ (2008) Underwater cards for assessing coral health on Caribbean reefs. GEF-Coral Reef Targeted Research Program, Center for Marine Sciences, St. Lucia

Willis BL, Page CA, Dinsdale EA (2004) Coral disease on the Great Barrier Reef. In: Rosenberg E, Loya Y (eds) Coral health and disease. Springer-Verlag, Berlin, p 69-104

Zuur AF, Ieno EN, Walker NJ, Saveliev AA, Smith GM (2009) Mixed effects models and extensions in ecology with R, 1st edn. Springer, New York, NY

Submitted: June 24, 2011; Accepted: May 16, 2012

Proofs received from author(s): August 9, 2012 